\title{
Urban design and therapeutic landscapes. Evolving theme
}

\author{
Monika Trojanowska \\ Department of Architecture and Urban Design; Faculty of Civil and Environmental Engineering \\ and Architecture; UTP University of Science and Technology in Bydgoszcz; \\ 7 prof. S.Kaliskiego Av., 85-796 Bydgoszcz, Poland; \\ monika.trojanowska@utp.edu.pl (D)0000-0001-8168-0746
}

\begin{abstract}
The global pandemic of COVID-19, which enforced strict isolation, demonstrated the responsibility of architects and planners for public health promotion. While the concept of therapeutic landscapes is rather new, the quest for designing health-promoting human environment is at least as old as urban planning. The garden suburbs of Ebenezer Howard and Patrick Geddes were planned to promote health and well-being. The ultimate goal of Le Corbusier was to provide daylight and fresh air to each apartment. However, towers in open green space, which were built according to his visions, turned into unfriendly large suburbs. Today, the definition of therapeutic landscapes encompasses not only physical aspects of environment but also social and psychological factors. This study focuses on attempts to create health-promoting places. The interesting question is what are the architectural features linked to health promotion? Although the individual perception of health-promoting places is subjective and may vary, there are some objective qualities of eco-neighbourhoods that are conducive to human health and longevity. This study combines literature review with field observation and resultes in the development of the conceptual framework which can be consolidated into the universal standards for health-promoting places.
\end{abstract}

Keywords: urban design; therapeutic landscapes; health promoting places; architecture

\section{Introduction. The concept of therapeutic landscapes}

The concept of therapeutic landscapes was coined by Wilbert Gesler to describe places which are believed to promote healing, for example Lourdes in France or Epidaurus in Greece [1]-[3]. Gesler defined therapeutic landscapes as places where "physical and built environments, social conditions and human perceptions combine to produce an atmosphere which is conducive to healing" [1, p. 96].

However, the design of healthy places is not the invention of XX century. It has always been the main concern for planners since antiquity. Marcus Vitruvius Polio (ca. 75 BC -15 BC) advised to carefully observe the behaviour of animals and test the environmental qualities 
before establishing new communities. He insisted on avoiding unhealthy places to build human settlements [4].

For centuries the natural beauty of landscape was an important factor when choosing a place to live. However, the situation changed dramatically after the industrial revolution. For vast majority of workers drawn to fast-growing cities there was no choice. The living conditions were repelling in poor XIX century districts. That drew the attention of many thoughtful inventors who searched for a solution. Albert Levy (2012) stipulates that three revolutions in medical sciences: Pasteur (1885), Freud (1900) and environmental revolution (1987) directly influenced the urban planning [5]. Can we expect the fourth COVID-19 revolution? The time will show.

\subsection{The garden suburbs of XIX century}

The Pasteur revolution (1885) in medical science might have impacted Ebenezer Howard (1850-1928) and Patric Geddes (1854-1932). At the end of the 19th century, they noticed that the traditional model of city surrounded by medieval fortifications was obsolete. Ebenezer Howard proposed a "gentle" revolution based on spatial separation of work and living [6]. He invented a method of urban planning in which small neighbourhoods were surrounded by greenbelts. Howard assumed that the garden city was the practical solution and alternative to the traditional city. The advantages were: possibility of contact with nature in the city and separation of pedestrians and vehicle traffic. From the very beginning he created a vision of sustainable city, without environmental pollution resulting from chaotic urbanization. Howard's ideas were further developed by Patrick Geddes. He created a vision of parks with museums, libraries, universities and other public facilities built inside [7]. Unfortunately, Ebenezer Howard's ideas were the origin of modern separation of functions. Howard created the foundations for social planning and social housing on one side, but also for modern zoning on the other.

Ebenezer Howard's ideas were quickly put into practice in the designs of new neighbourhoods in England - Hampstead Garden Suburbs, Letchworth and Welwyn. 

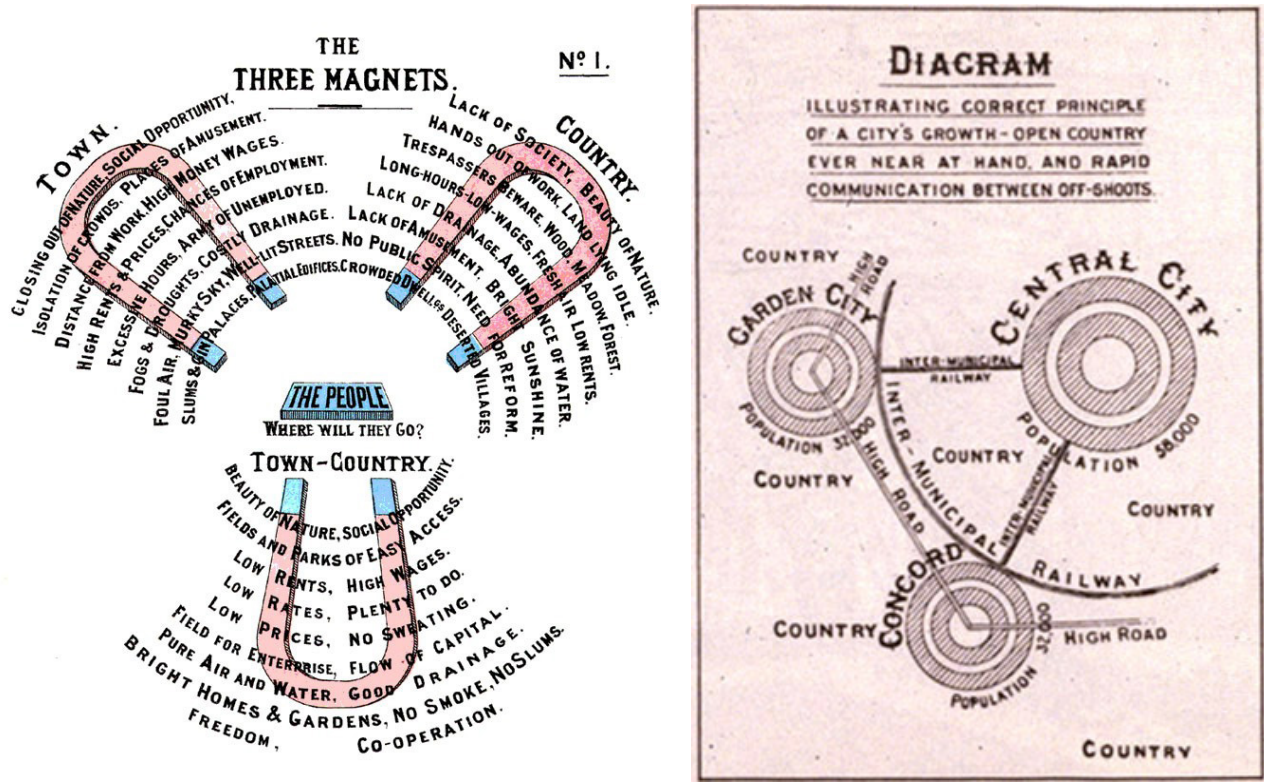

Fig. $1 \& 2 . \quad$ The scheme of garden suburbs, Source: [6]

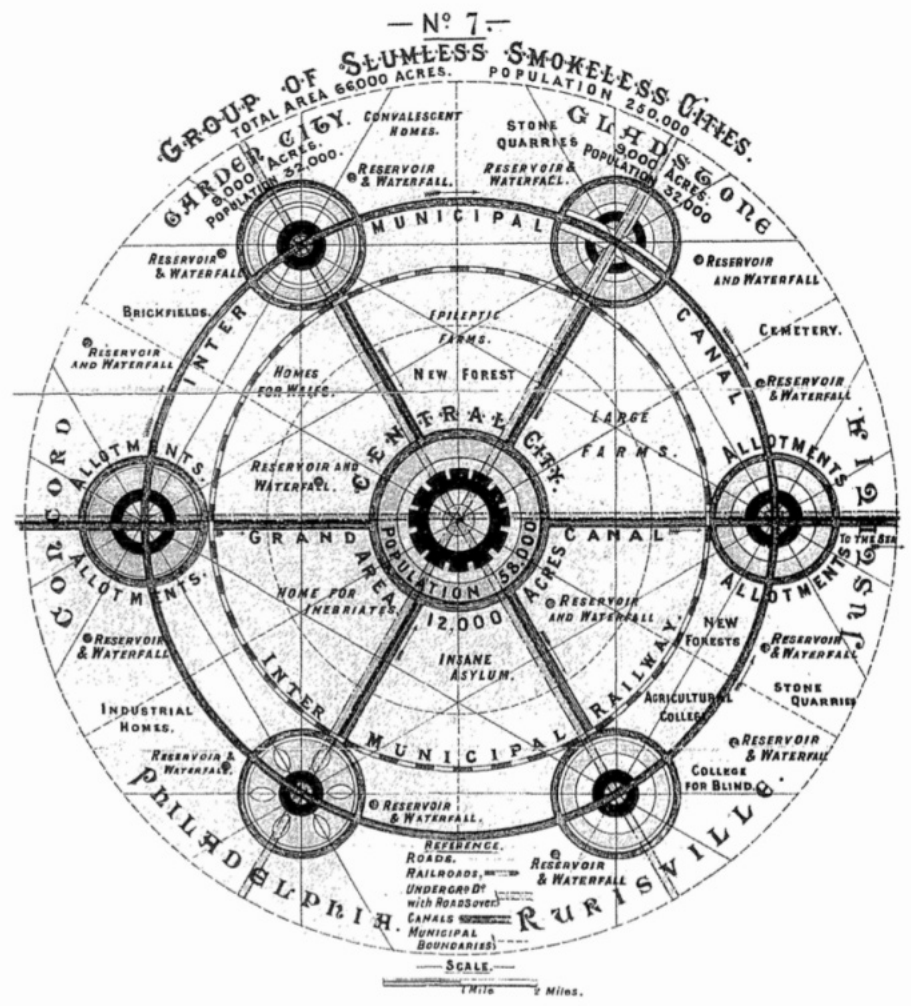

Fig. 3. The scheme of garden suburbs net, Source: [6] 


\subsection{Century neighbourhood}

In 1929, Clarence Arthur Perry presented the concept of neighbourhood unit for about 5,000 residents, where all basic facilities - school, church, shops - were located within walking distance from homes. The centre of the housing estate, where the services were to be located, was to become a centre of social life that would integrate residents. The concept of providing a full functional program in the centre of the district within the range of pedestrian path is one of the foundations of sustainable eco-neighbourhoods today.

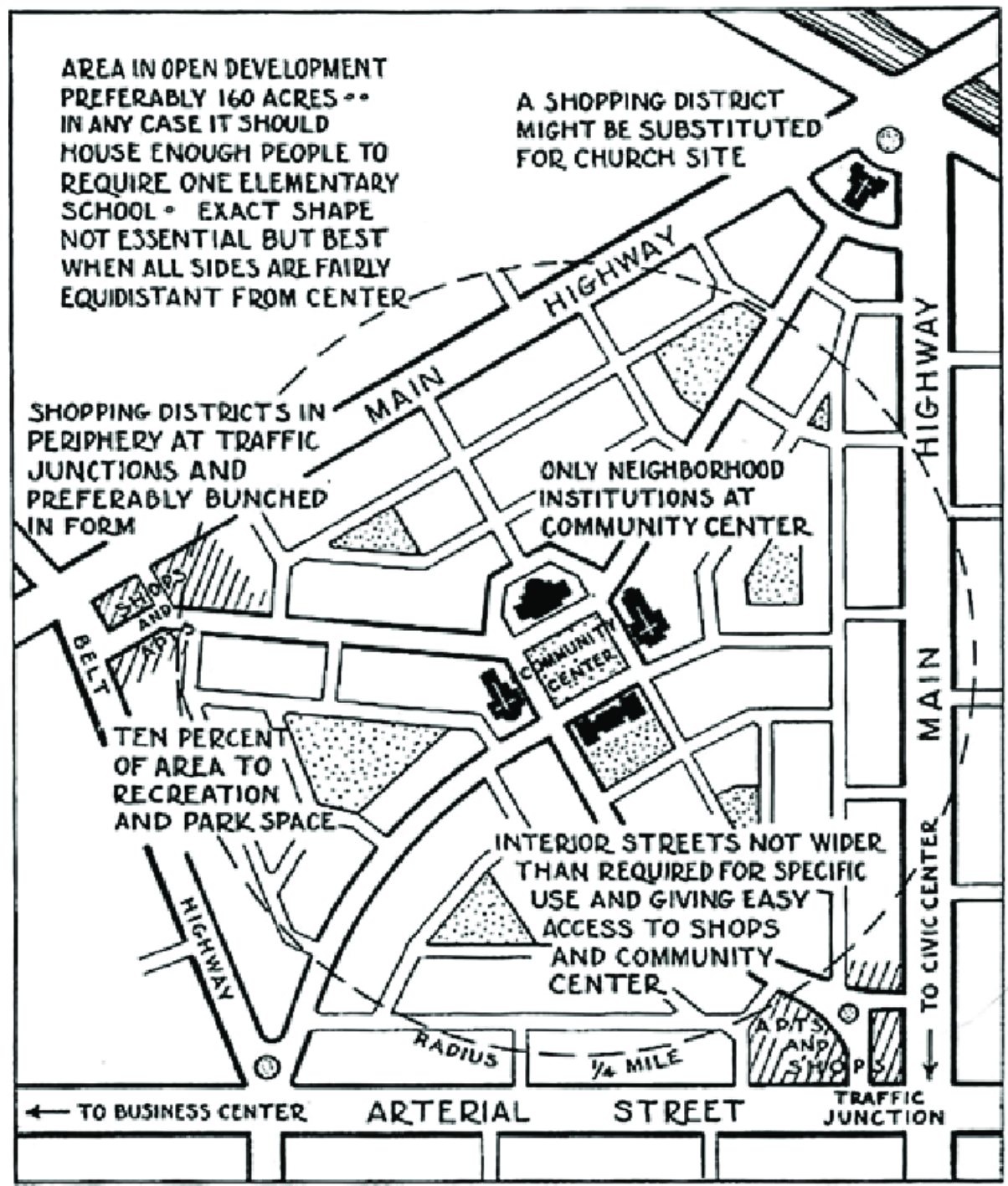

Fig. 4. Clarence Perry, Neighbourhood unit scheme, Source: [8]

Architects Clarence Stein and Henry Wright, inspired by the success of Letchworth and Welwyn in England, designed the city of Radburn in New Jersey. It was supposed to be a safe 
haven for children, because the pedestrian and vehicular traffic were separated. Architects proposed a new type of garden city adapted to car traffic. Traditional building quarters were replaced by superblocks, with an area of about 23 ha, off the main roads. Inside of the superblock there were the cul-de-sac - one way streets. The separation of pedestrian and vehicular traffic used in Radburn has become a popularly used way to ensure safe communication for pedestrians.

However, this solution also created some inconveniences. The problem of superblocks is the lack of an alternative access road to homes if the main access road is closed for any reason (accident, etc.). This urban solution has an impact on the increased formation of traffic jams during peak hours. Today, other ways to diminish the traffic are applied.
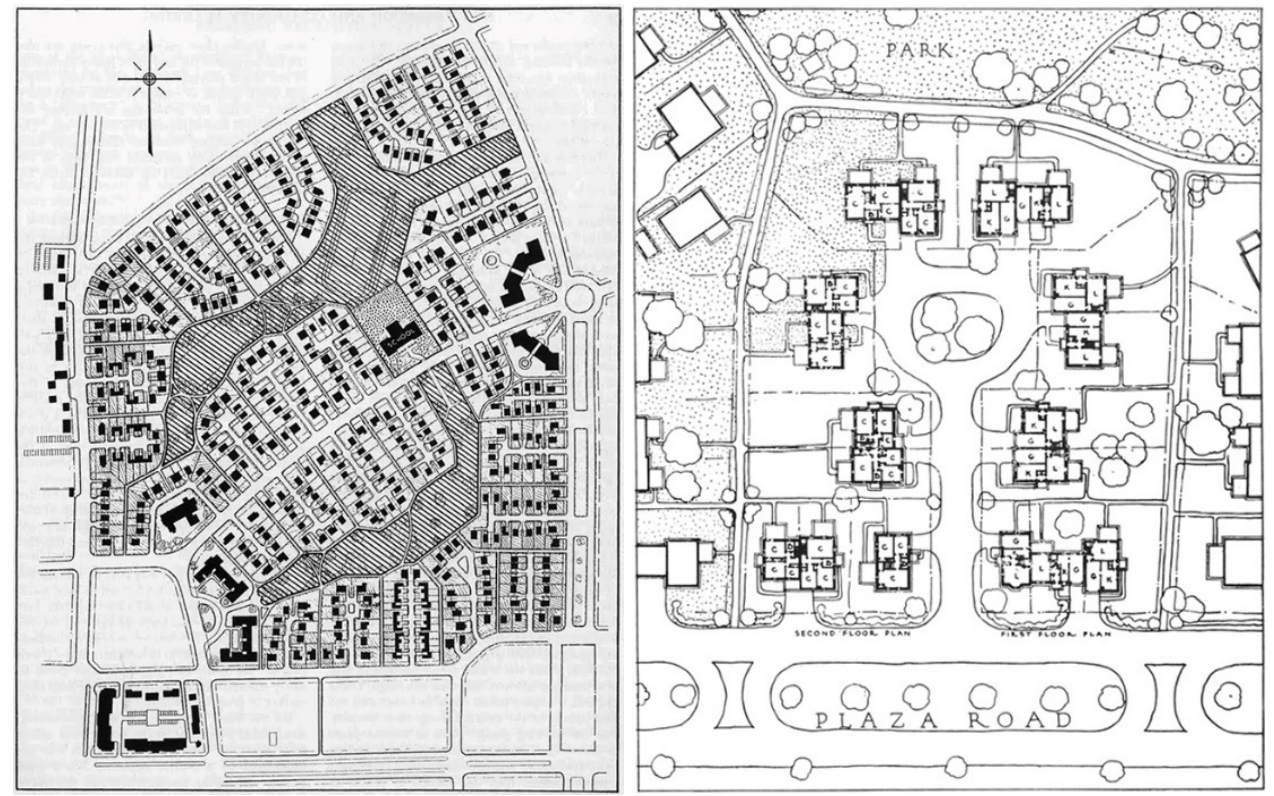

Fig. 5 \& 6. Radburn masterplan and cul-de-sac concept, Source: [9]

\subsection{Le Corbusier ultimate goal}

In 1933, the International Congress of Modern Architecture CIAM was organized. One of the leading figures at the CIAM congress was Charles Éduard Jeanneret - Le Corbusier (1887-1965). Le Corbusier proposed a complete departure from the traditional form of urban fabric. He proposed loosely arranged towers containing apartments, offices and accompanying functions instead of traditional quarters of buildings that make up the streets. He presented the Voisin de Paris plan, where he planned to demolish the historic buildings and replace them with office towers and lower service buildings. He also presented his plan for the suburbs Ville radieuse. As he said, it was a new, vertical model of garden city. The ultimate goal of Le Corbusier was to provide daylight and fresh air to each apartment. He wanted to provide residents with views of greenery. Le Corbusier's ideas, and especially the departure from the forms of buildings that created the street, had a great impact on post-war urbanism. However, towers in open green space, which were built according to his visions, turned into unfriendly large suburbs. 


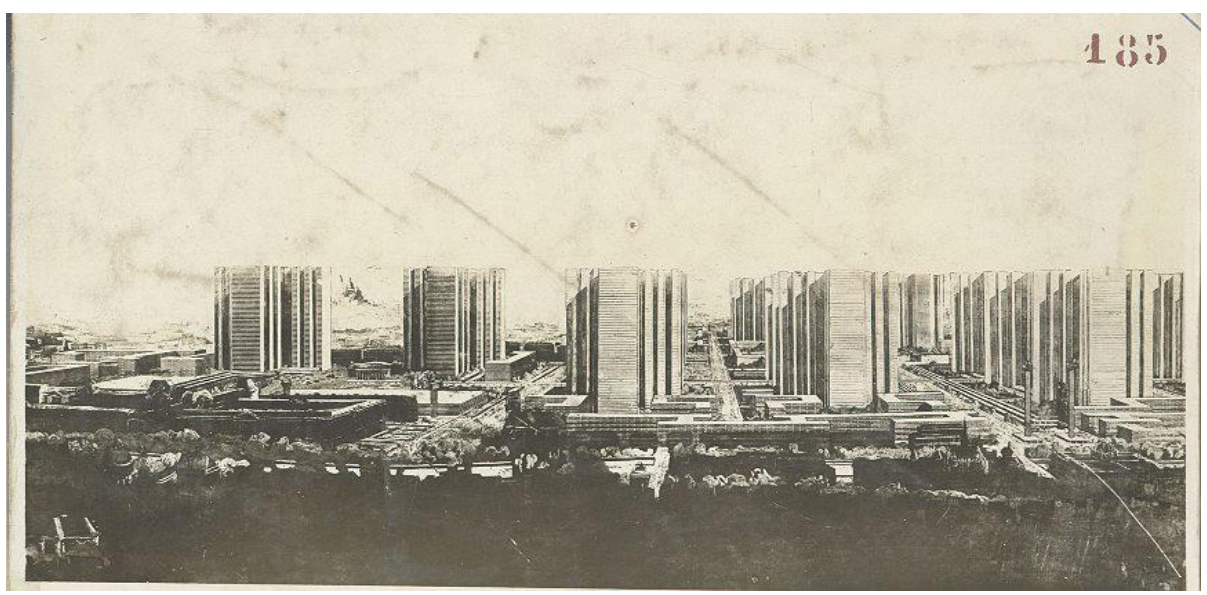

Fig. 7. The Plan Voisin for Paris redevelopment proposed by Le Corbusier Source: [10]

\subsection{Sad story of modernist garden suburbs}

The ideas of Le Corbusier opened the Pandora's box of modern large prefabricated housing districts. Typically, they were built very quickly using the industrialized methods on the outskirts of cities. Unfortunately, the inhabitants of those suburbs had to face numerous problems from the very beginning. Large scale of those districts totally excluded walkability. Many of those districts were totally deprived of services, leisure and sports facilities. Workplaces were located in other districts, thus, a lot of time was lost to commuting. The uniformity of buildings made it difficult to create mental maps. The public spaces were often neglected. There were no possibilities for creation of local identity. Sadly, more social problems accompanied modern suburbs. As a result, some of them had to be destroyed, for example Pruitt-Igoe neighbourhood in St. Louis, Missouri. Others, like the "Serpentine" public housing development in Pantin, France, needed urban regeneration. Modernist suburbs, zoning separation of functions and vehicle congested towns were a road to nowhere.
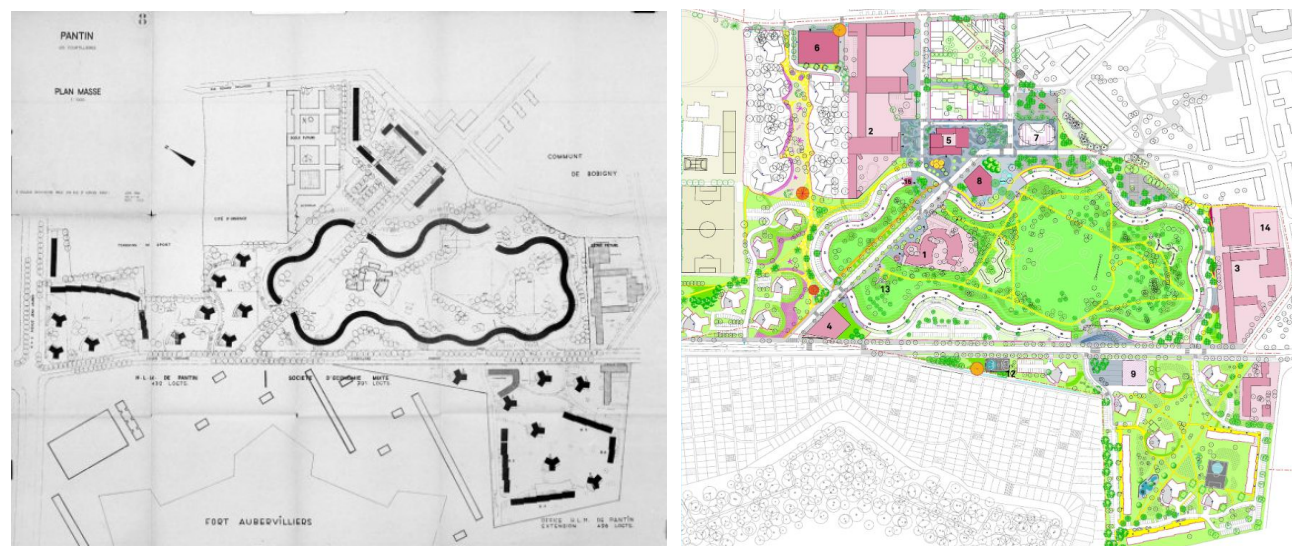

Fig. 8 (left). The "Serpentine" public housing development in Pantin, original masterplan, 1959, Source: [11]

Fig. 9 (right). The "Serpentine" public housing development in Pantin, urban regeneration project masterplan, 2006, Source: [12] 
Another problem brought by modern district design was suburban sprawl, which consumed agricultural lands in the outskirts of the city, destroying ecosystems and landscape values.

\section{Suburban sprawl}

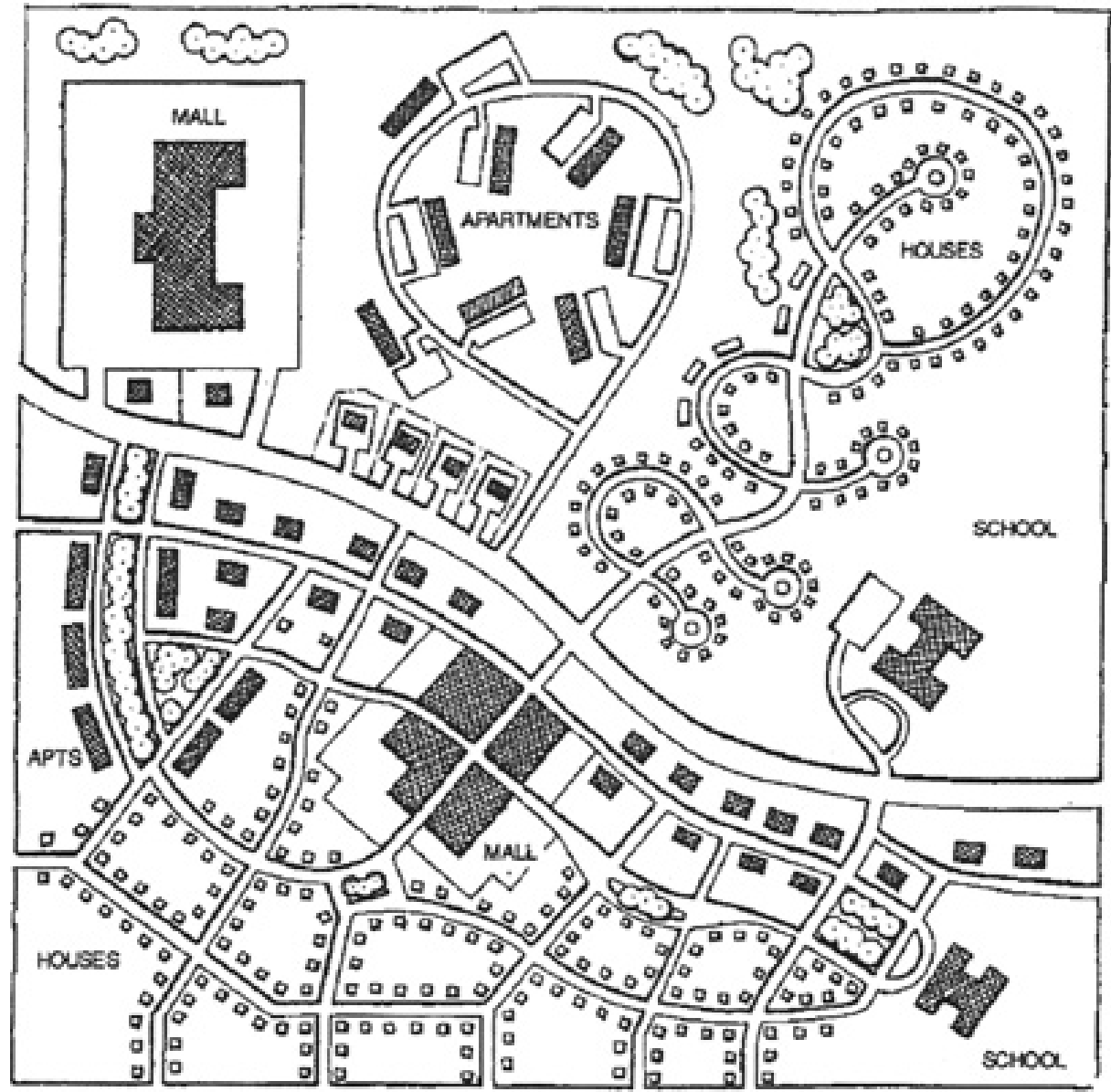

\section{Traditional neighborhood}

Fig. 10. Comparison of street networks and land use in sprawled (upper) and traditional (lower) neighbourhoods, Source: [13]

\subsection{Green urbanism once again. Return to traditional city?}

The sustainable development movement brought back interest in traditional urban forms. Yosef Rafeq Jabareen (2011) compared various typologies of urban tissue using following categories: Density, Diversity, Mixed land use, High Compactness, Sustainable, Passive solar design, Greening and Ecological design [14]. According to his opinion, the traditional urban form is the most sustainable. The international certificates, which assess the sustainability, for example EcoQuartier, HQE, BREAM, LEED Neighbourhood, etc. also stipulate traditional urban form. Typically, eco-neighbourhoods have larger quantity of green areas (about 1/3) and traditional urban layout with streets, facades and urban blocks [15]-[18]. Another impor- 
tant factor, typical for traditional cities and pivotal for eco-neighbourhoods, is the functional diversity. It supports the economic viability by creating nearby workplaces.

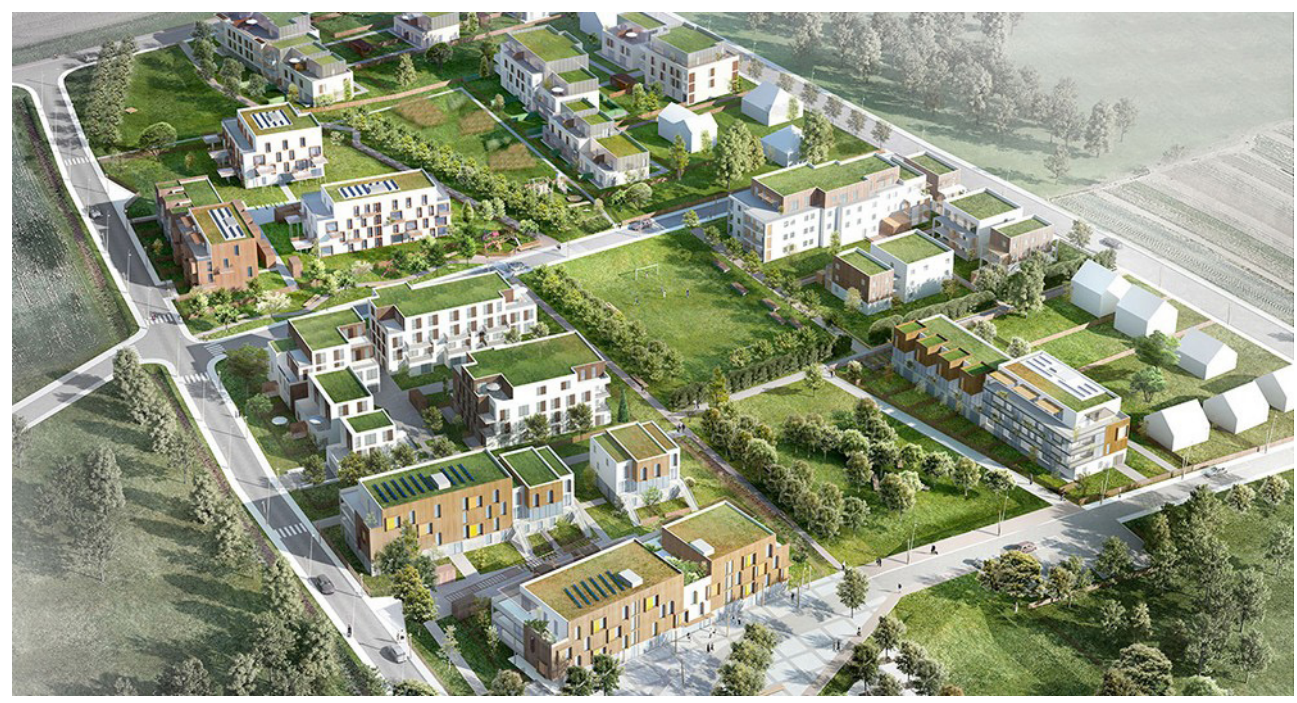

Fig. 11. Model of l'écoquartier des Meuniers, Bessancourt, France, Source: [19]

There are new ideas about the green city and therapeutic landscapes. One of them is the biophilic city. This concept derives from biophilia - the natural innate bond each human has with other living creatures. The biophilic city is a city which facilitates effortless everyday contact with nature to all inhabitants. That concept of city planning requires easy access to urban parks.

The new vision for salutogenic city presents neighbourhoods designed like large urban parks with buildings submerged in greenery. It derives from the concepts of Patric Geddes (public buildings in the park) and Le Corbusier (towers in greenery).

The old urban tissue is regenerated with the so-called new generation of urban parks, which let greenery sprawl into surrounding streets. The numerous small urban pocket parks create dense grid of green and blue infrastructure. Once again the greenery within city borders praised by Ebenezer Howard, Patric Geddes, Frederic Law Olmsted [20] and the hygienist movement in Europe (represented in Poland by Henryk Jordan), is regaining importance.

Today, the positive influence of urban parks is linked to psychological and physical regeneration, promotion of physical activity and social contacts [21]. Public parks are designed to accommodate all those needs.

\section{Purpose of the study. The universal pattern of design for health affirming urban places}

The impact of built environment on human health can be explained by multiple factors. This study focuses on possibilities to mitigate the negative environmental impact using architectural features and improve the architectural and urban design. The research question was what health-promoting qualities of built environment can be created and influenced by human 
actions. Firstly, the concept of therapeutic landscapes was studied, followed by health-promoting places and architectural features of salutogenic design.

\subsection{Therapeutic landscapes and health promoting places nowadays}

There are places and landscapes with established reputation for miraculous healing. Gesler [1, p. 96] defined therapeutic landscapes as places where "physical and built environments, social conditions and human perceptions combine to produce an atmosphere which is conducive to healing. " Be that as it may, the perceptions of therapeutic landscapes might be individual and subjective. Spaces that are perceived as therapeutic by one person could be experienced as unsettling for another [22], [23]. The term health-promoting places is more extensive and refers to everyday places that unite the qualities of therapeutic landscapes to influence people's physical, mental and spiritual healing.

\subsubsection{Method}

First, a review of traditional literature was carried out in order to find features identified by researchers as contributing to human comfort and well-being. This search can be defined as a scoping study on a broad topic to summarize and disseminate research findings [24]. The strategy involved hand-searching reference lists, key journals, electronic databases and existing networks [25]. The timeframe was limited to the final date of 2020. There was no start date. It was assumed that any findings are valuable, regardless of the date of research. This study led to a comprehensive list of attributes of human-friendly and health-promoting public spaces. The successive systematic literature review was undertaken to narrow search results to therapeutic landscapes. This search was conducted in January 2020 using the terms "therapeutic landscapes", within three comprehensive electronic databases (EBSCO, Web of Science, Scopus). Additional manual searches were conducted to identify recent publications in this field of study (checking the contents tables of 'Health and Place', 'Landscape Journal', 'Social Science and Medicine', and 'Urban Greening and Forestry'). The term "therapeutic landscapes" was initially introduced by Gesler in 1992, therefore the search dates ranged from 1992 to January 2020. Search was narrowed to full-text scientific papers. This search returned 114 results. Study of SCOPUS with "therapeutic landscapes" 2011-2020 full text returned 155 results. Search through Web of Science returned 388 results.

\subsubsection{Results}

This study's objective was to establish a comprehensive list of common features of therapeutic landscapes which were mentioned in literature. Although the focus was primarily on the therapeutic landscapes and research identified via the scoping review, the wider bodies of literature were consulted. The methodology consisted of content analysis. The results are presented in Table 1. 
Table 1. Results of the literature review. Attributes of health-promoting places. Source: Author RESULTS OF LITERATURE REVIEW. ATTRIBUTES OF HEALTH-PROMOTING PLACES

Material aspects - physical and built environment conducive to health-promotion

1. Access to public park

Distance to open public park $\quad$ Physically close, visible and easily accessible. [23], [26]

Pathways to park

[27], [28]

2. Functional program

Psychological and physical regeneration

Natural Landscapes

Forested land [34], [37]

coastlines, woodland, and riverside environ-

ments [23].

Natural physical beauty

Magnificent scenery

[23],

tranquillity, beauty and remoteness [41] natural [40]-[42]

physical beauty [42]

Green open space

Savannah like prairies, open clearings in the

[30], [32], woods.

[43]- 47]

Presence of Water

Preference of natural, meandering water banks

covered with plants.

[22], [23],

Therapeutic value of water

[29]-[32],

[42].

[35]-[37],

Presence of water (rivers, lakes and foun-

[39], [40],

tains) [37]

[42], [44],

Coastal environment [52].

[48]-[52]

Place to rest in the sun and in the shade

A clearing with lots of sunshine, a place open

[48]-[50]

to the south

Place to rest in silence and solitude

Secluded garden.

[23],

The pleasure garden, sense of enclosure.

[26]-[29],

Places protected from the wind, direst sunshine [38],

embodied restoration

[43], [45],

sense of calmness and peace,

[46], [48],

peaceful, quiet place.

[53]-[55]

Possibility to observe other people

Possibility to observe the others without being seen.

[26], [30],

Contact with surrounding life.

[46], [47]

Possibility to observe animals

Rich in species of birds. Contact with

[22], [23], surrounding life, sights, sounds, and move-

[26], [37]

ments of certain types of wildlife.

Physical Activity Promotion

Sports and recreational infrastructure

Points of activity every $100 \mathrm{~m}$.

[46],

Activity pockets.

[48], [53]

Attractive equipment.

Equipment for various sports.

Sports infrastructure (tennis, soccer field, base-

ball court, badminton, cycling path, etc.).

\begin{tabular}{lll}
\hline Attractive equipment for all age groups & $\begin{array}{l}\text { Places for teenagers, children, adults, dog } \\
\text { owners, etc. }\end{array}$ & $\begin{array}{l}{[46],[49],} \\
{[50]}\end{array}$ \\
\hline Community gardens & $\begin{array}{l}\text { Garden for hortitherapy. } \\
\text { Communal gardening on allotment sites. } \\
\text { Community gardening. }\end{array}$ & {$[3],[21],[23]$,} \\
& {$[57]-[61]$} \\
\hline Space for particular users & $\begin{array}{l}\text { Creative play for children. } \\
\text { Equipment for teenagers. }\end{array}$ & {$[36]$,} \\
& & {$[48]-[50]$,} \\
& & {$[62]$}
\end{tabular}




\begin{tabular}{|c|c|c|}
\hline \multirow{2}{*}{\multicolumn{3}{|c|}{$\begin{array}{l}\text { RESULTS OF LITERATURE REVIEW. ATTRIBUTES OF HEALTH-PROMOTI } \\
\text { Material aspects - physical and built environment conducive to health-promotion }\end{array}$}} \\
\hline & & \\
\hline \multicolumn{3}{|c|}{ Catering for basic needs } \\
\hline Safety and security & $\begin{array}{l}\text { Secure to use without risking any physical } \\
\text { unpleasantness. }\end{array}$ & $\begin{array}{l}{[26],[32],} \\
{[45],[63]}\end{array}$ \\
\hline Places to sit and rest & $\begin{array}{l}\text { Places to rest and meditate adjacent to the } \\
\text { pathways with controlled microclimate thanks } \\
\text { to plants, water and lighting. } \\
\text { Easy to control- np. movable chairs, choice } \\
\text { of places to sit - height, material of the bench, } \\
\text { armrests, etc. }\end{array}$ & {$[48]-[50]$} \\
\hline Shelter & $\begin{array}{l}\text { Sheltered places to sit and rest. } \\
\text { 'Refuge'- a place to hide from danger or } \\
\text { threats. }\end{array}$ & $\begin{array}{l}{[27],[28],} \\
{[53],} \\
{[55],[59]}\end{array}$ \\
\hline Restrooms & & [49], [50] \\
\hline Drinking water & & [49], [50] \\
\hline Food & Stands with food. & [48]-[50] \\
\hline \multicolumn{3}{|l|}{ 3. Organization of space and functions } \\
\hline \multicolumn{3}{|l|}{ Architectural variety of urban environment } \\
\hline Focal points and landmarks & Landmark, Central point, Dominant point, etc. & $\begin{array}{l}{[27]-[29],} \\
{[35],} \\
{[48],[53]}\end{array}$ \\
\hline $\begin{array}{l}\text { Structure of interiors and connections } \\
\text { Legibility }\end{array}$ & $\begin{array}{l}\text { Hierarchy of open spaces. Orientation and way } \\
\text { finding. }\end{array}$ & $\begin{array}{l}{[26],[31],} \\
{[32],[43],} \\
{[44],[46],} \\
{[47]-[50],} \\
{[64]-[67]}\end{array}$ \\
\hline Pathways with views & $\begin{array}{l}\text { Possibility to choose among many pathways, } \\
\text { alternative way, accessible pathways; Continu- } \\
\text { ous loops, paths to determined places. } \\
\text { Pathways with interesting views. } \\
\text { 'Prospect' - having an overall grand view of } \\
\text { the landscape, with potential for discovering } \\
\text { resources. }\end{array}$ & $\begin{array}{l}{[27]-[29],} \\
{[49],[50],} \\
{[59],[65]}\end{array}$ \\
\hline $\begin{array}{l}\text { Invisible fragments of the scene (Vista } \\
\text { engaging the imagination) }\end{array}$ & Vista engaging the imagination. & $\begin{array}{l}{[30],[43],} \\
{[44],[47]}\end{array}$ \\
\hline Framed views & & {$[48]-[50]$} \\
\hline Human scale & $\begin{array}{l}\text { Distances small enough to determine human } \\
\text { face expression and mimics, hear the human } \\
\text { voice. }\end{array}$ & $\begin{array}{l}{[29],[35],} \\
{[48],} \\
{[54],[68]}\end{array}$ \\
\hline Optimal level of complexity & Legible elements of complex composition. & $\begin{array}{l}{[33],[35],} \\
{[43],[44],} \\
{[47],[54]}\end{array}$ \\
\hline \multicolumn{3}{|l|}{ Engaging features } \\
\hline Controlled Risk/Peril & $\begin{array}{l}\text { Source of shimmering noise - e.g. fountain, } \\
\text { instruments, etc., a mountain to climb on. }\end{array}$ & [47], [30], \\
\hline Movement & $\begin{array}{l}\text { Calm and slowly moving water,breaking waves, } \\
\text { boats bobbing up and down, cyclical changes } \\
\text { created by the tides, and moments of intensity } \\
\text { created by patterns of light hitting the water. }\end{array}$ & $\begin{array}{l}{[23],[30],} \\
{[33]}\end{array}$ \\
\hline
\end{tabular}




\begin{tabular}{lll}
\hline \multicolumn{3}{l}{ RESULTS OF LITERATURE REVIEW. ATTRIBUTES OF HEALTH-PROMOTING PLACES } \\
\hline \begin{tabular}{lll} 
Material aspects - physical and built environment conducive to health-promotion & \\
\hline $\begin{array}{lll}\text { Sensory stimuli (Sight, Hearing, Smell, } \\
\text { Touch, Taste and Spatial Orientation) }\end{array}$ & $\begin{array}{l}\text { Pleasurable multisensory immersion. } \\
\text { embodied relationships with specific scents. }\end{array}$ & $\begin{array}{l}\text { [23], [27], } \\
\text { [28], } \\
\text { 4. Sustainability }\end{array}$ \\
\hline Biodiversity protection. & \multicolumn{3}{l}{} \\
& $\begin{array}{l}\text { Rich in species; A room with various species of } \\
\text { plants and animals, rich in flowers and fruits. }\end{array}$ & {$[29],[32]$,} \\
& Rich in habitat and exotic species. & {$[46]$,} \\
& Rich in species of birds and animals. & {$[69],[70]$}
\end{tabular}
\end{tabular}

\begin{tabular}{|c|c|c|}
\hline Native animals & Fascination with nature. Habitat species. & $\begin{array}{l}{[36],[45],} \\
{[47],} \\
{[48],[70]}\end{array}$ \\
\hline Native plants & Natural succession of plants. & $\begin{array}{l}{[29],[32],} \\
{[37],[45],} \\
{[47],} \\
{[48],[70]}\end{array}$ \\
\hline \multicolumn{3}{|c|}{ Attributes which promote social contacts } \\
\hline Organization of events & $\begin{array}{l}\text { Space for attractive events, meaningful activ- } \\
\text { ity, social life characterized by bonds of trust, } \\
\text { reciprocity and cooperation. }\end{array}$ & [23], [46] \\
\hline Gathering place for groups & $\begin{array}{l}\text { Environment for being together. } \\
\text { Place for integration of all age groups in open } \\
\text { green space. } \\
\text { Social opportunities. }\end{array}$ & $\begin{array}{l}{[26],} \\
{[37],[45]}\end{array}$ \\
\hline Safety & $\begin{array}{l}A \text { sense of security, inclusion, and belonging } \\
\text { over time. }\end{array}$ & [23], [38] \\
\hline \multicolumn{3}{|c|}{ Attributes related to human perceptions - spiritual and symbolic } \\
\hline Placemaking & $\begin{array}{l}\text { Strong positive sense of place, symbolic and } \\
\text { cultural values; monuments, theatres, exposi- } \\
\text { tion pavilions, etc. }\end{array}$ & $\begin{array}{l}{[22],[23]} \\
{[38],[45]} \\
{[69],[71]}\end{array}$ \\
\hline Culture and connection to the past & $\begin{array}{l}\text { Place with fascinating history. } \\
\text { The use of paintings and statues. } \\
\text { Community-based heritage conservation. }\end{array}$ & $\begin{array}{l}{[23],[30],} \\
{[37],[40],} \\
{[45],[46]} \\
{[71],[72]}\end{array}$ \\
\hline Sacred places & $\begin{array}{l}\text { Access to sacred places in open public green } \\
\text { space, } \\
\text { sacred pilgrimage sites, holy wells and springs, } \\
\text { land of miraculous healing. }\end{array}$ & $\begin{array}{l}{[2],[3],[22],} \\
{[23],[27],} \\
{[28],[42],} \\
{[48],[73]}\end{array}$ \\
\hline Personalization, participation of $u$ & & {$[26],[36]$} \\
\hline
\end{tabular}




\subsubsection{Space characteristics linked to therapeutic qualities}

The key review findings were summarized into material, social, spiritual and symbolic dimensions as initially referred to by Gesler to characterize therapeutic landscapes (1996, p.96). In the beginning, it was presumed that the health-promoting places unite the therapeutic attributes, but therapeutic landscapes are places of established reputation of well-known places of healing, thus the spiritual and symbolic aspects give them an additional advantage. The research evidence suggests that social capital is explicitly linked to well-being and fostering recovery [38], [74], [75]. The literature review suggested that the material aspects can construct human-friendly public spaces, but the social conditions are needed to create health-promoting places, while the spiritual and symbolic aspects further define therapeutic landscapes (Fig. 12).

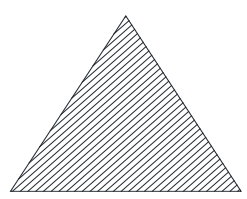

HUMAN FRIENDLY PUBLIC SPACE

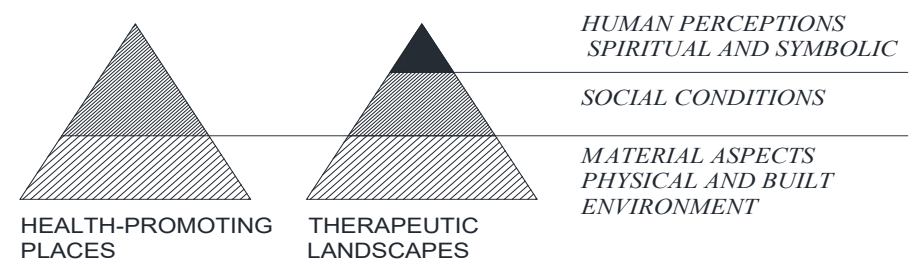

$\begin{array}{ll}\text { HEALTH-PROMOTING } & \text { THERAPEUTIC } \\ \text { PLACES } & \text { LANDSCAPES }\end{array}$

Fig. 12. Diagram showing the attributes directly related to therapeutic landscapes overlapping general qualities of human -friendly public space, Source: [76]

\subsection{A universal pattern of design for health promoting urban landscapes}

The studies of literature and field observations led to development of a conceptual framework presented in Table 2 . 
Table 2. A universal standard for health-promoting urban places. Source: Author, [76]

A UNIVERSAL STANDARD FOR HEALTH-PROMOTING URBAN PLACES.

\begin{tabular}{|c|c|c|c|c|}
\hline 1. SUSTAINABILITY & 2. ACCESSIBILITY & 3. AMENITIES & 4. DESIGN & 5. PLACEMAKING \\
\hline \multirow{6}{*}{$\begin{array}{l}\text { 1.1. Place } \\
\text { Area } \\
\text { Location } \\
\text { Surrounding urban } \\
\text { pattern }\end{array}$} & \multirow[t]{2}{*}{ 2.1. Distance to park } & \multirow{2}{*}{$\begin{array}{l}\text { 3.1. Psychological } \\
\text { and physical }\end{array}$} & \multirow{2}{*}{$\begin{array}{l}\text { 4.1. Architectural } \\
\text { design }\end{array}$} & \multirow{2}{*}{$\begin{array}{l}\text { 5.1. Enhancement of } \\
\text { Social Contacts }\end{array}$} \\
\hline & & & & \\
\hline & \multirow{4}{*}{$\begin{array}{l}\text { 2.2. Sidewalk } \\
\quad \text { Infrastructure- } \\
\text { Width of sidewalk } \\
\text { Evenness of surface }\end{array}$} & \multirow{3}{*}{$\begin{array}{l}\quad \text { regeneration } \\
\text { Natural } \\
\text { Landscapes }\end{array}$} & \multirow{3}{*}{$\begin{array}{l}\text { Human scale } \\
\text { Focal points and } \\
\text { landmarks }\end{array}$} & \multirow{4}{*}{$\begin{array}{l}\text { Organization of } \\
\text { events } \\
\text { Meeting places for } \\
\text { groups }\end{array}$} \\
\hline & & & & \\
\hline & & & & \\
\hline & & Green open space & \multirow{2}{*}{$\begin{array}{l}\text { Structure of inte- } \\
\text { rior connections }\end{array}$} & \\
\hline \multirow{2}{*}{$\begin{array}{l}\text { 1.2. Environmental } \\
\text { characteristics }\end{array}$} & Lack of obstructions & Presence of water & & \multirow{4}{*}{$\begin{array}{l}\text { 5.2. Human } \\
\text { perception } \\
\text {-spiritual \& } \\
\text { symbolic }\end{array}$} \\
\hline & $\begin{array}{l}\text { Slope } \\
\text { Sufficient drainage }\end{array}$ & Places to rest in & Framed views & \\
\hline $\begin{array}{l}\text { Soil quality } \\
\text { Water quality }\end{array}$ & Sufticien & the sun shade & Long vistas & \\
\hline $\begin{array}{l}\text { water quality } \\
\text { Air quality }\end{array}$ & 2.3. General & Places to rest in & (Extent) & \\
\hline Noise level & conditions of & & $\begin{array}{l}\text { Pathways with } \\
\text { views }\end{array}$ & Sacred places \\
\hline Forms of natural & Maintenance & $\begin{array}{l}\text { 3.2. Promotion } \\
\text { of Physical }\end{array}$ & Invisible parts of & Works \\
\hline protection & Overall aesthetics & Activities & the scenery (Vistas & Cultur \\
\hline $\begin{array}{l}\text { Green and Blue } \\
\text { Infrastructure }\end{array}$ & Street art & Sports and & $\begin{array}{l}\text { hich engage the } \\
\text { gagination) }\end{array}$ & connections \\
\hline & Sufficient seating & recreational & ssibility to & to the past \\
\hline 1.3. Biodiversity & Perceived safety & infrastructure & watch other people & Thematic gardens \\
\hline protection & Buffering from traffic & & Possibility to see & Personalization \\
\hline Parts of open green & Street activities & & wildlife & \\
\hline $\begin{array}{l}\text { space not available to } \\
\text { visitors }\end{array}$ & Vacant lots & $\begin{array}{l}\text { Addressing the } \\
\text { needs of people }\end{array}$ & 4.2. Salutogenic & \\
\hline Native plants & 2.4. Traffic & with d & desigr & \\
\hline Native animals & Speed & & Optimal levels of & \\
\hline Natural maintenance & Volume & basic needs & complexity & \\
\hline methods & Number and safety of & Safety and & Engaging features & \\
\hline 1.4. Sustainable water & $\begin{array}{l}\text { crossings } \\
\text { Stop signs }\end{array}$ & security (presence & $\begin{array}{l}\text { Risk } \\
\text { Mystery/Fasci- }\end{array}$ & \\
\hline management & On-street parking & cleanliness, & nation & \\
\hline Rainwater infiltration & & maintenance, etc.) & Movement & \\
\hline $\begin{array}{l}\text { Irrigation with } \\
\text { non-potable water }\end{array}$ & $\begin{array}{l}\text { 2.5. User Experience } \\
\text { Air quality }\end{array}$ & $\begin{array}{l}\text { Places to sit and } \\
\text { rest }\end{array}$ & 4.3. Sensory & \\
\hline 1.5. Parks of Second & Noise level & Shelter & stimuli design & \\
\hline (New) Generation & Sufficient lighting & Restrooms & Sensory stimuli: & \\
\hline & Sunshine and shade & Drinking water & Sen & \\
\hline 1 & Visibility of nearby & Food (possibility & Hearing & \\
\hline 1.7. Ecological energy & & the park or in the & Sensory stimuli: & \\
\hline & 2.6. Public transport & & Smell & \\
\hline & & & $\begin{array}{l}\text { Sensory stimuli: } \\
\text { Touch }\end{array}$ & \\
\hline & 2.7. Sufficient Parking & & Sensory stimuli: & \\
\hline & & & Taste & \\
\hline & & & Sensory path & \\
\hline
\end{tabular}

The field study focused on attempts to create health-promoting places in modern eco-neighbourhoods. Eco-neighborhoods were chosen because they are to promote a healthy lifestyle for both people and our planet. They are funded on principles of environmental, ecological, and social responsibility. Site observation of modern sustainable neighbourhoods in Europe confirmed that majority of attributes of health promoting places are present in their design. 


\subsection{Material aspects - physical and built environment conducive to health-promotion}

\subsubsection{Accessibility}

Eco-neighbourhoods have a larger proportion of natural open spaces comparing to traditional urban tissue - approximately one third of their urbanized surface. Usually, they are designed with centrally located urban park.

\section{- Walking distance to points of interest}

The frequency of walking was found to depend upon the distance to a local points of interest. A Danish study showed that respondents living closer than 300 meters to open green space are more likely to be physically active and less likely to be stressed than those living further away from parks [56], [57]. Researchers confirm the importance of attractive walkways [27], [28], [77]. Eco-neighbourhoods are designed as multi-functional neighbourhoods, where all the basic everyday needs could be fulfilled within walking distance. Eco-neighbourhoods propose a multifunctional dense urban tissue that promotes walkability.

\subsubsection{Amenities}

\section{- Psychological and physical regeneration}

Health promoting landscapes are often associated with places to rest in silence and solitude away from the noise and the hassle of everyday struggles [45], [46], [66]. The majority of eco-neighbourhoods are designed with a centrally located public park i.e. Hammarby Sjöstad in Stockholm, ZAC Clichy-Batignolles in Paris, ZAC Trapeze Boulogne-Billancourt, etc.

- Window view of greenery

In the eco-neighbourhoods visited, it was assumed that each apartment should have at least one window overlooking the greenery (Fig. 13).

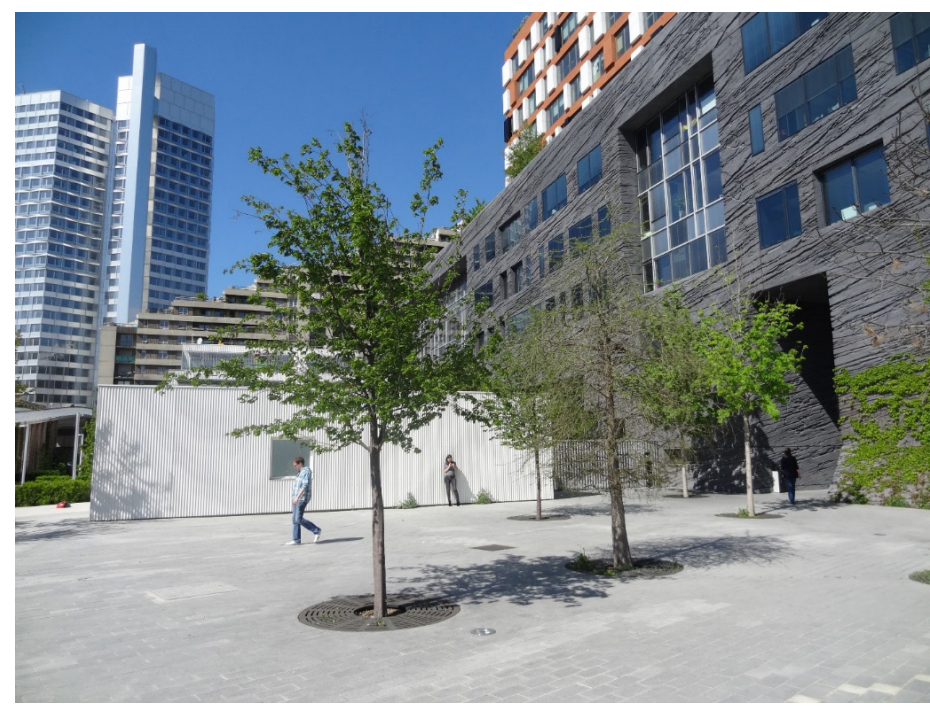

Fig. 13. Public space with tree planters. ZAC Trapeze, Boulogne-Billancourt, France, Source: Author 
- Promotion of physical activity

Careful design of public open green space can promote moderate to vigorous physical activity. Physical activity is directly linked to health promotion, well-being and longevity [77], [78] (Fig. 14).

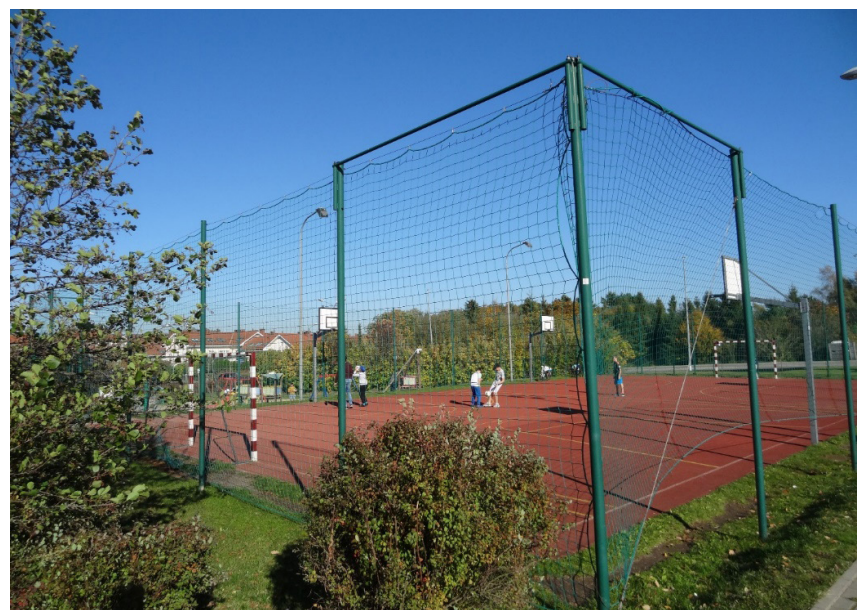

Fig. 14. Sport field. Gdynia-Zachód, Poland, Source: Author

\subsubsection{Design}

\section{- Architectural variety}

The field study of modern sustainable neighbourhoods in Europe demonstrated the creation of architectural variety. Each of the building blocks or even individual buildings were designed by a different architect in accordance with specific requirements stipulated by the general masterplan: not only the building dimensions and setbacks but also choice of materials, textures, and colours (Fig. 15).

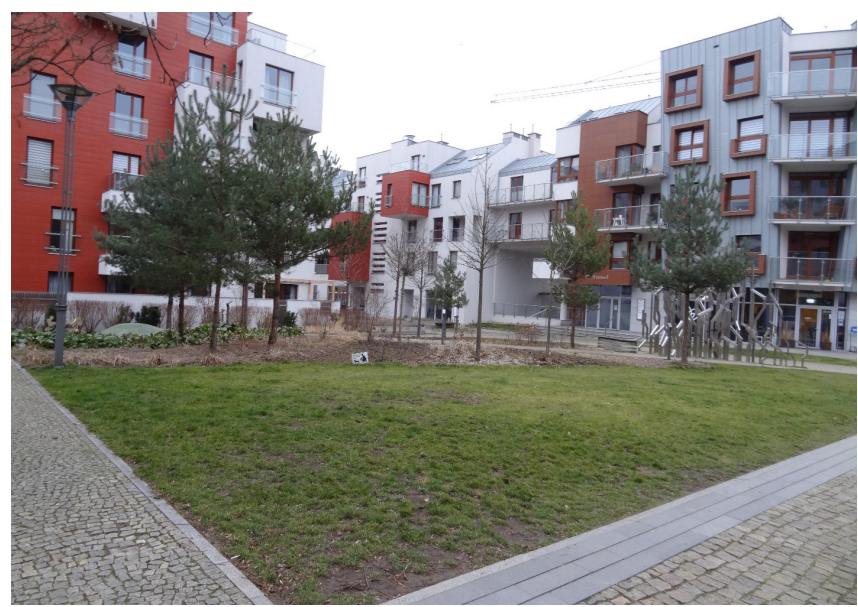

Fig. 15. Modern courtyard with visible architectural diversity and sustainable planting design. Gdańsk, Poland, Source: Author 
- The physical beauty of the environment

Contact with natural physical beauty is believed to be a salutogenic experience. Magnificent scenery is associated with the therapeutic landscape. The therapeutic landscapes of well-established reputation e.g. Lourdes in France or St. Anne de Beaupre in Quebec, Canada, or Epidaurus in Greece - unite the natural physical beauty of the landscape with sacred and symbolic qualities.

\section{- Legibility}

Eco- neighbourhoods are structured in a coherent pattern. Our brain needs a certain hierarchy of open spaces, landmarks and central points, etc. to construct mental maps, facilitate orientation and wayfinding. The urban form of eco-neighbourhoods is quite traditional [17].

- Optimal level of complexity

If we look at the successful modern neighbourhoods, we can recognise patterns of complexity of construction elements, symmetry and repetitious rhythms. Human mind needs a certain level of complex composition, orderly frames and intricate details to stimulate our brains.

\section{- Attributes which promote social contacts}

One of the key elements of health promotion is to facilitate the social contacts. Even superficial contacts, like saying hello to a stranger or sharing a bench, can have a beneficial influence on human health [79]-[86]. That factor is especially important for the potentially isolated and disadvantaged social groups (elderly, disabled, etc.) The therapeutic properties of a landscape depend on the social context of the place [2].

- Attributes related to human perceptions - spiritual and symbolic

Many researchers documented the spiritual meaning of healing and the positive relationship between spiritual activity and good health and well-being [27], [28], [42], [48]. Modern planning with randomly scattered large blocks of flats deprived people of details. Today, we can observe how the urban regeneration projects are working towards implementing architectural variety of details once again. Building facades and openings are getting decorated by more or less intricate individualized ornaments to help create architectural diversity and individual qualities of urban places. The biophilic city, like the traditional city, is full of details, materials and scents, which facilitates the creation of mental maps.

\section{- Integrating health in urban and territorial planning: A sourcebook}

A new sourcebook by UN-Habitat was published in 2020 during the COVID-19 pandemic. It can be regarded as a sourcebook resulting from Health in all policies paradigm, putting forward the objective of sustainable development and promotion of human health. UN emphasize the need to put human health in the centre of urban and territorial planning. This work is divided into nine chapters. One of the chapters is dedicated to health impact assessment as one of the methods for environmental justice protection. The sourcebook starts with words "the way we plan and build our cities defines our quality of life" [87]. Today, it defines our health even more than before.

\section{Conclusions}

The history of urban design seems to be a revolving theme. After almost a century of modernist designed suburbs, the new approach returns to traditional urban forms. Nonetheless, there are new imperatives e.g. the presence of open green spaces, daylighting and affordance of views of greenery, which make the difference between the ninetieth century urban blocks 
and the eco-neighbourhoods of today. The sustainability and new concepts of biophilic cities and health-affirming urban landscapes are novelty in contemporary urban planning.

Urban health-affirming landscapes are everyday places which unite the qualities of therapeutic landscapes to promote physical, mental and spiritual healing [88]. The concept of therapeutic landscapes stipulates not only environmental, but also social factors. A psychological grid of social contacts and connection with the place of living are important therapeutic factors.

Therefore, modern planning of a healthy city is more oriented towards developing processes of town growth, not only on designing the structures [89]. The participation of inhabitants is crucial to create place identity and bonds with place of living. We might see that it is a revolving theme because, from the ancient times, the city dwellers were actively developing their own houses and often they were taking part in local municipal governments. The large scale modernist urban planning lost that dimension which triggered negative effects. Today, we are trying to rebuild that connection.

This study resulted in the development of the conceptual framework that can be consolidated into the universal standards for health-promoting places. The evaluation tool could help designers to fully include the research evidence in modern eco-neighbourhoods. It could also be helpful in creating a strategy for urban regeneration projects. The identified limitation of use of this tool for assessment comes directly from the subjectivity of individual perception. While the majority of therapeutic attributes can be assessed objectively, some are subjective. Therefore, the universal pattern should not be used as a tool for statistical comparison of therapeutic values of different parks, but rather as an assessment one.

\section{Acknowledgement}

Special thanks to Zofia Kukurowska from UTP University of Science and Technology in Bydgoszcz, for explication and assistance during the systematic literature review.

\section{References}

[1] Gesler W., "Lourdes: healing in a place of pilgrimage", Health \& Place, vol. 2, no.2, (1996), pp. 95-105. https://doi.org/10.1016/1353-8292(96)00004-4

[2] Gesler W., "Therapeutic Landscapes: An evolving theme", Health \& Place, vol. 11, no. 4, (2005), pp. 295-297. https://doi.org/10.1016/j.healthplace.2005.02.003

[3] Cooper-Marcus C., Sachs N., Therapeutic Landscapes. An Evidence-Based Approach to Designing Healing Gardens and Restorative Outdoor Spaces. Hoboken, New Jersey : John Wiley \& Sons, Inc., 2014.

[4] Vitruvius M., Ten Books on Architecture. Cambridge: Cambridge University Press, 1999.

[5] Lévy A., Ville, urbanisme et santé- Les trois revolutions. Pascal Editions, 2012.

[6] Howard E., Garden Cities of To-morrow. London, 1902.

[7] Baty-Tornikian G., La ville satellite. Des cités-jardins aux écoquartiers. CNDP, 2013.

[8] Clarence A.P., The neighborhood unit. Regional New York and Its Environs, Monograph I. Volume VII, New York, 1929, Available: https://en.wikipedia.org/wiki/Clarence_Perry\#/media/File:New_ York_Regional_Survey,_Vol_7.jpg [Accessed: 1 Dec 2019]

[9] Stein C., Wright H., «Radburn superblock», arquiscopio. Available: http://arquiscopio.com/ archivo/2013/04/28/supermanzana-de-radburn/?lang=en) [Accessed: 1 Dec 2019]

[10] Le Corbusier, The Plan Voisin for Paris redevelopment. Available: http://www.fondationlecorbusier.fr/corbuweb/morpheus.aspx?sysId=13\&IrisObjectId=6159\&sysLanguage=en-en\&itemPos $=2 \&$ itemCount $=2 \&$ sysParentName=Home\&sysParentId=65), [Accessed: 1 Dec 2019] 
[11] Les Courtillières, plan masse, juin 1956, modifié en octobre 1958, 1/1000e. Available: http://www. msaudcolumbia.org/summer/?p=3404) [Accessed: 1 Dec 2019]

[12] SEMIP, Pantin-Pru Des Courtillieres. Available: http://www.semip.net/files/uploads/ope/pdf_236. pdf) ) [Accessed: 1 Dec 2019]

[13] Spielberg F., The traditional neighborhood development: how will traffic engineers respond? ITE J. 1989;59:17, "Drawing by Duany Plater Zyberk". Available: http://pediatrics.aappublications. org/content/123/6/1591.figures-only [Accessed: 1 Dec 2019]

[14] Jabareen Y.R., "Sustainable Urban Forms: Their Typologies, Models, and Concepts", Journal of Planning Education and Research, vol. 26, (2006) pp.38-52. https://doi.org/10.1177/0739456X05285119

[15] Charlot-Valdieu C., Outrequin P., Developpement durable et renouvellement urbain. Des outils operationnels pour ameliorer la qualite de vie dans nos quartiers. Paris : L'Harmattan, 2006.

[16] Charlot-Valdieu C., Outrequin P., Concevoir et évaluer un projet d'écoquartier. Paris: Editions Le Moniteur, 2012.

[17] Souami T., Écoquartiers. Secrets de fabrication. Analyse critique d'exemples européens. Paris: Les Carnets de l'info, 2011.

[18] Souami T., "ÉcoQuartiers et urbanisme durable", Problemes politiques et sociaux, no. 981, 2011. https://doi.org/10.4000/developpementdurable.9038

[19] Piffareti A., "Bessancourt s'offre un écoquartier. Grand Paris Aménagement livre les 300 premiers logements du nouvel écoquartier en juin. Fin de l'opération en 2021/2022". Available: https:// www.lesechos.fr/11/05/2016/LesEchos/22189-370-ECH_bessancourt-s-offre-un-ecoquartier. htm [Accessed: 1 Dec 2019]

[20] Garvin A., Public Parks. The key to livable communities. New York: W.W. Norton \& Company, Inc, 2011.

[21] Cooper-Marcus C., Francis C., People places. Design Guidelines for Urban Open Space. New York: John Wiley \& Sons, 1998.

[22] Bell S. L., Wheeler B.W., Phoenix C., "Using Geonarratives to Explore the Diverse Temporalities of Therapeutic Landscapes: Perspectives from "Green" and "Blue" Settings", Annals of the American Association of Geographers, vol. 107 no. 1 (2017), pp. 93-108. https://doi.org/10.108 0/24694452.2016.1218269

[23] Bell S.L. et al., "From therapeutic landscapes to healthy spaces, places and practices: A scoping review", Social Science \& Medicine. Vol. 196, (2018), pp. 123-130. https://doi.org/10.1016/j. socscimed.2017.11.035

[24] Arksey H., O’Malley L., "Scoping Studies: Towards a Methodological Framework", International Journal of Social Research Methodology, vol. 8, no. 1, 2005, pp. 19-32. https://doi. org/10.1080/1364557032000119616

[25] Therapeutic Landscapes Network, Available: http://www.healinglandscapes.org/search/sitemap. html [Accessed: 1 Dec 2019]

[26] Bengtsson A., Grahn P., "Outdoor environments in healthcare settings: A quality evaluation tool for use in designing healthcare gardens", Urban Forestry \& Urban Greening, vol. 13, no. 4, 2014, pp. 878-891. https://doi.org/10.1016/j.ufug.2014.09.007

[27] Rosenblatt Naderi J., Landscape Design in the Clear Zone: The Effect of Landscape Variables on Pedestrian Health and Driver Safety. Available : swuc.tamu.edu/publications/papers/167425TP2. pdf [Accessed: 1 Dec 2019]

[28] Rosenblatt Naderi J., "Design of walking environments for spirituals renewal", in Proceedings - Walk21-V Cities for people, The fifth International Conference on Walking in the 21 st century, 2004, Available : http://citeseerx.ist.psu.edu/viewdoc/download?doi=10.1.1.570.8464\&rep=rep1\&type=pdf, [Accessed: 1 Dec 2019]

[29] Lynch K., The image of the city. Cambridge: MIT Press, 1964. 
[30] Heerwagen J., Gregory B., "Biophilia and Sensory Aesthetics", in: Kellert S., Heerwagen J., Mador M. ed., Biophilic design: the theory, science, and practice of bringing buildings to life Hoboken, New Jersey: John Wiley \& Sons, 2008.

[31] Ulrich R., "View through a window may influence recovery from surgery", Science, vol. 224, no. 4647, (1984), pp. 420-421. https://doi.org/10.1126/science.6143402

[32] Ulrich R., "Effects of Gardens on Health Outcomes: Theory and Research", in: Cooper Marcus C., Barnes M., Healing Gardens, Hoboken, New Jersey: John Wiley \& Sons, 1999.

[33] Ulrich R., "Biophilic Theory and Research for Healthcare Design", in: Kellert S., Heerwagen J., Mador M., (Ed.), Biophilic design: the theory, science, and practice of bringing buildings to life Hoboken, New Jersey: John Wiley \& Sons, 2008.

[34] Morita E., et al.,"Psychological effects of forest environments on healthy adults: Shinrin-yoku (forest-air bathing, walking) as a possible method of stress reduction", Public Health, vol. 121, no.1, 2007, pp. 54-63. https://doi.org/10.1016/j.puhe.2006.05.024

[35] Harting T., Bringslimark T., Patil GG., "Restorative Environmental Design: What, When, Wher, and for Whom? ”, in: Kellert S., Heerwagen J., Mador M. ed., Biophilic design: the theory, science, and practice of bringing buildings to life Hoboken, New Jersey: John Wiley \& Sons, 2008, pp. 133.

[36] Moore R.C., Cooper -Marcus C., "Healthy Planet, Healthy Children: Designing Nature into the Daily Spaces of Childhood" in: Kellert S., Heerwagen J., Mador M. ed., Biophilic design: the theory, science, and practice of bringing buildings to life Hoboken, New Jersey: John Wiley \& Sons, 2008, pp. 153.

[37] Colesca S.E., Alpopi C., "The Quality of Bucharest's Green Spaces”, Theoretical and Empirical Researches in Urban Management, vol. 6, no. 4, 2011, pp. 45-59. Available : https://www.jstor. org/stable/pdf/24873301.pdf, [Accessed: 1 Dec 2020]

[38] Duff C., 2012 "Exploring the role of 'enabling places' in promoting recovery from mental illness: a qualitative test of a relational model", Health \& Place, vol. 18, no. 6, 2012, pp. 1388-1395. https://doi.org/10.1016/j.healthplace.2012.07.003

[39] Foley R., Kistemann T., "Blue space geographies: enabling health in place. Introduction to special issue on healthy blue space”, Health \& Place, vol. 35, 2015, pp. 157-165. https://doi.org/10.1016/j. healthplace.2015.07.003

[40] Huang L., Xu H., "Therapeutic landscapes and longevity: Wellness tourism in Bama", Social Science \& Medicine, vol. 197, 2018, pp.24-32. https://doi.org/10.1016/j.socscimed.2017.11.052

[41] Kearns R.A., Collins D., "New Zealand children's health camps: therapeutic landscapes meet the contract state", Social Science \& Medicine, vol. 51, no. 7, 2000, pp. 1047-1059. https://doi. org/10.1016/S0277-9536(00)00020-4

[42] Williams A., "Spiritual therapeutic landscapes and healing: A case study of St. Anne de Beaupre, Quebec, Canada", Social Science \& Medicine, vol. 70, no. 10, 2010, pp. 1633-1640. https://doi. org/10.1016/j.socscimed.2010.01.012

[43] Kaplan S., "The restorative benefits of nature-Towards an integrative framework", Journal of Environmental Psychology, vol. 15, no. 3, 1995, pp. 169-82. https://doi.org/10.1016/0272-4944( 95)90001-2

[44] Kahn P.H., The Human Relationship with Nature. Development and Culture. Cambridge : The MIT Press, 1999.

[45] Grahn P. et al., "A planning model for designing sustainable and healthy cities. The importance of people's need of recreational environments in an urban context", in Proceedings NAEP (National Assoc. of Environmental Professionals) $30^{\text {th }}$ Annual Conference, Alexandris VA, USA, 16-19 april 2005. Available : https://www.researchgate.net/publication/237616933_A_planning_model_for_ designing_sustainable_and_healthy_cities_The_importance_of_people $\% 27 \mathrm{~s} \_n e e d$ _of_recreational_en-_vironments_in_an_urban_context [Accessed: 23 Jan 2021] 
[46] Lis A., Struktura podłoża motywacyjnego zachowań użytkowników parków miejskich. Wrocław: Wydawnictwo Akademii Rolniczej we Wrocławiu, 2005.

[47] Hildebrand G., "Biophilic Architectural Space”, in: Kellert S., Heerwagen J., Mador M. (Ed.), Biophilic design: the theory, science, and practice of bringing buildings to life Hoboken, New Jersey: John Wiley \& Sons, 2008.

[48] Alexander Ch., Język wzorców. Translated from: A pattern language. Towns-Buildings-Construction, Oxford University Press 1977, Gdańskie Wydawnictwo Psychologiczne, 2008.

[49] Saelens B.E. et al., "Measuring Physical Environments of Parks and Playgrounds: EAPRS Instrument Development and Inter-Rater Reliability", Journal of Physical Activity and Health, vol. 3, no. 1, 2006, pp. 190-207. https://doi.org/10.1123/jpah.3.s1.s190

[50] Saelens B., Environmental Assessment of Public Recreation Spaces (EARPS) Tool Available : www.activelivingresearch.org, [Accessed: 23 Jan 2021]

[51] White M. et al., "Blue Space: The importance of water for preferences, affect and restorativeness ratings of natural and built scenes", Journal of Environmental Psychology, vol. 30, 2010, pp.482-493. https://doi.org/10.1016/j.jenvp.2010.04.004

[52] Satariano B., "Blue therapeutic spaces on islands: Coastal landscapes and their impact on the health and wellbeing of people in Malta", Island Studies Journal, vol. 14, no. 2, 2019, pp. 245-260. https://doi.org/10.24043/isj.100

[53] Mehta V., Bosson J.K., "Third Places and the social Life of Streets", Environment and Behavior, vol. 42, no. 6, 2010, pp. 779-805. https://doi.org/10.1177/0013916509344677

[54] Mahan A., Golestani S., Meschi M., "Pedestrian street and walkability: Studying the effect of type and quality of adjacent usage in walkability of pedestrian street", in: Dymitryszyn I., Kaczyńska M., Maksymiuk G., The power of landscape, Warsaw: SGGW, 2012.

[55] Lewicka M., Psychologia miejsca. Warszawa: Wydawnictwo Naukowe Scholar, 2012.

[56] Stigsdotter U.A, Grahn P., "What Makes a Garden a Healing Garden? ”, Journal of Therapeutic Horticulture, vol.13, 2002, pp. 60-69. Available: https://www.brikbase.org/sites/default/files/ What\%20Makes\%20a\%20Garden\%20a\%20Healing\%20Garden.pdf [Accessed: 23 Jan 2021]

[57] Stigsdotter U.A., "Urban Green Spaces: Promoting Health through City planning" in Proceedings - The National Association of Environmental Professionals' NAEP, $30^{\text {th }}$ Annual Conference, Inspiring Global Environmental Standards and Ethical Practices. 16-19 April 2005, Alexandria, Virginia USA. Available: https://www.researchgate.net/profile/Ulrika_Stigsdotter/publication/266883592 URBAN GREEN SPACES PROMOTING_HEALTH THROUGH CITY PLANNING/links/5476f0170cf29afed6143887/URBAN-GREEN-SPACES-PROMŌTINGHEALTH-THROUGH-CITY-PLANNING.pdf [Accessed: 23 Jan 2021]

[58] Grahn P., Bengtsson I.L, Welen-Andersson L.et al. (2004). “Alnarp Rehabilitation Garden: possible health effects from the design, from the activities and from the therapeutic team Swedish University of Agricultural Sciences", in Proceedings - Martens, B.; Keul, A.G. (eds.), Evaluation in Progress - Strategies for Environmental Research and Implementation IAPS 18 Conference Proceedings 7-9 July 2004, Available: https://www.researchgate.net/publication/265037411_Alnarp_Rehabilitation_Garden_possible_health_effects_from_the_design_from_the_activities_and_from_the therapeutic_team/link/5446618b0cf22b3c14de1edd/download [Accessed: 23 Jan 2021]

[59] Milligan Ch., Gatrell A., Bingley A., 'Cultivating health': therapeutic landscapes and older people in northern England”, Social Science \& Medicine, vol. 58, no. 9, 2004, pp. 1781-1793. https://doi. org/10.1016/S0277-9536(03)00397-6

[60] Völker S., Kistemann T., «I'm always entirely happy when I'm here!» Urban blue enhancing human health and well-being in Cologne and Düsseldorf, Germany", Social Science \& Medicine, vol. 78, no. 1, 2013, pp. 113-124. https://doi.org/10.1016/j.socscimed.2012.09.047 
[61] Litt J.S. et al., "Exploring ecological, emotional and social levers of self-rated health for urban gardeners and non-gardeners: A path analysis", Social Science \& Medicine, vol. 144, 2015, pp. 1-8. https://doi.org/10.1016/j.socscimed.2015.09.004

[62] Oldenburg R., The great good place. Da Capo Press, 1989.

[63] Czyński M., “Architektura, stres i potrzeba bezpieczeństwa”, Przestrzeń i Forma, no. 10, 2008.

[64] Olmsted F.L., "Public Parks and the Enlargement of towns", in: Thompson I., Rethinking Landscape, London and New York: Routledge, 2009.

[65] Antonovsky A., "The salutogenic model as a theory to guide health promotion", Health Promotion International vol 11, no. 1, 1996, pp. 11-18. Available : https://salutogenesi.org/images/PDF/ The_salutogenic_model_as_a theory_to_guide_health_promotion.pdf [Accessed: 23 Jan 2021]

[66] Kaplan R., Kaplan S., Ryan R.L,. With People in Mind. Design and Management of Everyday Nature.Washington D.C., Covelo, California: Island Press, 1998.

[67] Moulay A., Ujang N., Said I., "Legibility of neighborhood parks as a predicator for enhanced social interaction towards social sustainability”, Cities, vol. 61, 2017, pp. 58-64. https://doi.org/10.1016/j. cities.2016.11.007

[68] Gehl J., Cities for people. Island Press, 2010.

[69] Day S., "Place and the experience of air quality", Health \& Place, vol. 13, no. 1, 2007, pp. 249-260. https://doi.org/10.1016/j.healthplace.2006.01.002

[70] Rink D, Herbst H., "From wasteland to wilderness - aspects of a new form of urban nature", in Richter M, Weiland U, editors. Applied urban ecology: A global framework. Chichester, UK: Wiley-Blackwell, 2011, pp. 82-92. https://doi.org/10.1002/9781444345025.ch7

[71] Williams A., "Therapeutic landscapes in holistic medicine", Social Science \& Medicine, vol. 46, no. 9, 1998, pp. 1193-1203. https://doi.org/10.1016/S0277-9536(97)10048-X

[72] Power A, Smyth K., "Heritage, health and place: The legacies of local community-based heritage conservation on social wellbeing", Health \& Place. vol.39, 2016, pp. 160-167. https://doi. org/10.1016/j.healthplace.2016.04.005

[73] Perriam G., "Sacred spaces, healing places: therapeutic landscapes of spiritual significance", The Journal of Medical Humanities, vol. 36, no. 1, 2015, pp. 19-33. https://doi.org/10.1007/ s10912-014-9318-0

[74] Wakefield S., McMullan C., "Healing in places of decline: (Re)imagining everyday landscapes in Hamilton, Ontario", Health \& Place, vol. 11, no. 4, 2006, pp. 299-312. https://doi.org/10.1016/j. healthplace.2004.05.001

[75] Sampson R., Gifford S.M., "Place-making, settlement and well-being: the therapeutic landscapes of recently arrived youth with refugee backgrounds", Health \& Place, vol. 16, no. 1, 2010, pp. 116-131. https://doi.org/10.1016/j.healthplace.2009.09.004

[76] Trojanowska M., Poszukiwanie standardu projektowania ekoosiedli w Polsce. Bydgoszcz: Wydawnictwa Uczelniane Uniwersytetu Technologiczno-Przyrodniczego w Bydgoszczy, 2020.

[77] Takano T, Nakamura K., Watanabe M., "Urban residential environments and senior citizens' longevity in megacity areas: the importance of walkable green spaces", Journal of Epidemiology Community Health, vol. 56, 2002, pp. 913-918. http://dx.doi.org/10.1136/jech.56.12.913

[78] Ward J.S., Duncan J.S., Jarden A., Steward T., "The impact of children's exposure to greenspace on physical activity, cognitive development, emotional wellbeing, and ability to appraise risk", Health \& Place, vol. 40, 2016, pp. 44-50. https://doi.org/10.1016/j.healthplace.2016.04.015

[79] CABE Commission for Architecture and the Built Environment, Community green: using local spaces to tackle inequality and improve health. London, 2010.

[80] Kuo F., Bacaicoa M., Sullivan W., "Transforming Inner-City Landscapes. Trees, Sense of Safety, and Preference", Environment and Behaviour, vol 30. no. 1, 1998, pp. 28-59. https://doi. org/10.1177/0013916598301002 
[81] Kuo F., Sullivan W., "Environment and crime in the inner city. Does Vegetation Reduce Crime?", Environment and Behaviour, vol. 33, no. 3, 2001, pp. 343-367. https://doi. org/10.1177/0013916501333002

[82] Kuo F., Parks and Other Green Environments: Essential Components of a Healthy Human Habitat. National Recreation and Park Association, 2010.

[83] Sempik J., Aldridge J., Becker S., Growing Together - a practice guide to promoting social inclusion through gardening and horticulture. Bristol: The Policy Press, 2005.

[84] Sempik J., Aldridge J., Becker S., Health, Well-being and Social Inclusion. Therapeutic Horticulture in the UK. Bristol: The Policy Press, 2005

[85] Maas J., Verheij, R.A., "Morbidity is related to a Green living environment", J Epidemiol Community Health ,vol. 63, 2009, pp. 967-973. http://dx.doi.org/10.1136/jech.2008.079038

[86] Mass J. et al., "Social contacts as possible mechanism behind the relation between Green space and health", Health and Place, vol. 15, no. 2, 2009, pp. 586-595. https://doi.org/10.1016/j.healthplace.2008.09.006

[87] WHO, UN-Habitat Integrating health in urban and territorial planning: A sourcebook, 2020. Available : https://unhabitat.org/integrating-health-in-urban-and-territorial-planning-a-sourcebookfor-urban-leaders-health-and [Accessed: 23 Jan 2021]

[88] Trojanowska M., Sas-Bojarska A., „Health-affirming everyday landscapes in sustainable city. Theories and tools", Architecture, Civil Engineering, Environment, no. 3/2018, pp. 53-61. https:// doi.org/10.21307/ACEE-2018-038

[89] Baranowski A., "Energooszczędność procesów rozwoju miasta i jego struktur" in : Budownictwo energooszczędne w Polsce - stan i perspektywy, Bydgoszcz: Wydawnictwo Uczelniane Uniwersytetu Technologiczno-Przyrodniczego w Bydgoszczy, 2015. 
